\title{
Performance of a water defluoridation plant in a rural area in South Africa
}

\author{
JJ Schoeman* \\ University of Pretoria, Department of Chemical Engineering, Water Utilisation Division, Pretoria, South Africa
}

\begin{abstract}
The fluoride concentration of a borehole water supply in a rural area (Madibeng Local Municipality, North West Province, South Africa) varies between 5 and $6 \mathrm{mg} / \ell$. This water is therefore not suitable for potable purposes because the high fluoride concentration may cause mottling of tooth enamel in children and fluorosis in adults. Therefore, the fluoride concentration should be reduced to less than $1.5 \mathrm{mg} / \ell$ to make the water suitable for potable purposes. The activated alumina and reverse osmosis processes are both processes that can be very effectively applied for water defluoridation. The activated alumina process, however, is considered to be a more simple and robust process for water defluoridation, especially in a rural area. Therefore, the activated alumina process was selected for water defluoridation. An activated alumina plant was designed, constructed and commissioned in the rural area. Fluoride in the feed water is removed from 6 to $8 \mathrm{mg} / \ell$ to less than $1.5 \mathrm{mg} / \ell$. No reduction in plant output was experienced over 6 service cycles. Therefore, it appears that fouling of the activated alumina should not be a problem. Plant output varied between 940 and $1296 \mathrm{~m}^{3}$ to a fluoride breakthrough of approximately $2.0 \mathrm{mg} / \ell$. No significant operational problems were experienced during commissioning and the plant is performing satisfactorily. Spent regenerant is disposed of into evaporation ponds. It was demonstrated that a $1^{\text {st }}$ world technology could be effectively applied in a rural area with proper training and supervision of the operators. The capital and operational costs of the $200 \mathrm{~m}^{3} / \mathrm{d}$ defluoridation plant are estimated at approximately $\mathrm{R} 1.2 \mathrm{~m}$. and $\mathrm{R} 0.7 / \mathrm{m}^{3}$ treated water.
\end{abstract}

Keywords: water defluoridation, activated alumina, plant performance, costs

\section{Introduction}

The fluoride concentration of borehole water in a rural area (Madibeng Local Municipality, North West Province, South Africa) varies between 5 and $6 \mathrm{mg} / \ell$. This water is therefore not suitable for potable purposes because its high fluoride concentration will cause mottling of the tooth enamel in children and fluorosis in adults (Holden, 1970; Bishop and Sancoucy, 1978). The fluoride concentration should be reduced to $<1.5 \mathrm{mg} / \ell$ to make the water suitable for potable purposes (South African Water Quality Guidelines, 1996). The required demand for defluoridated water is $200 \mathrm{~m}^{3} / \mathrm{d}$ over an $8 \mathrm{~h}$-period or $1400 \mathrm{~m}^{3} / \mathrm{d}$ per week.

A number of methods are reported for the removal of fluoride from water. These can be divided into three categories: those based on the addition of chemicals to cause precipitation or coprecipitation during coagulation (Beneberu, 2006; Mekonen, 2001; Turner et al., 2005), those based upon ion-exchange or adsorption (Coetzee et al, 2003; Agarwal et al., 2003; Jamode et al., 2004 ) and those based upon membrane separation technologies ( Schoeman and Steyn, 2000; Sordo et al., 1998; Tahaikt et al., 2006; Menkouchi et al., 2007). Of these methods, the activated alumina process appears to be the most suitable because alumina has a relatively high fluoride-exchange capacity. Activated alumina is not very friable and is not seriously affected by chlorides and sulphates in concentrations usually encountered. Regeneration which can be performed with caustic soda is fairly straightforward and the process seems to be reliable, safe and

* To whom all correspondence should be addressed.

前 +2712 420-3569; fax: +2712 362-5089;

e-mail: japie.schoeman@up.ac.za

Received 12 December 2007; accepted in revised form 20 November 2008. relatively simple to use. The process can remove fluoride in the feed-water concentration range from 4 to $20 \mathrm{mg} / \ell$ to $<1 \mathrm{mg} / \ell$. The activated alumina process was therefore selected for water defluoridation in the study area.

The objectives of this paper are to report on the performance of the defluoridation plant during commissioning and on the economics of the process.

\section{Fluoride quality requirements}

The US Environmental Protection Agency has made the maximum allowable fluoride concentration for drinking purposes dependent on climatic conditions (Drinking Water Standards, 1962) because the amount of water consumed and, consequently, the amount of fluoride ingested, is temperature-related.

The maximum allowable concentrations are shown in Table 1 (National Interim Primary Drinking Water Regulations, 1975) as are the recommended fluoride concentrations established by the US Public Health Service (Drinking Water Standards, 1962).

The SA Bureau of Standards (1971) has recommended a limit of $1 \mathrm{mg} / \ell$ for fluoride in drinking water supplies and has set the maximum allowable concentration at $1.5 \mathrm{mg} / \ell$.

\section{The activated alumina process}

Activated alumina $\left(\mathrm{Al}_{2} \mathrm{O}_{3}\right)$ functions as an anion exchanger and the common anions are selected in the following order by acid treated activated alumina (Clifford et al., 1978).

$$
\mathrm{OH}^{-}>\mathrm{PO}_{4}{ }^{3-}>\mathrm{F}^{-}>\mathrm{SO}_{3}{ }^{2-} ;>\mathrm{SO}_{4}{ }^{2-}>>\mathrm{NO}_{2}{ }^{2-}>\mathrm{Br}^{-}>\mathrm{Cl}^{-}>\mathrm{NO}_{3}^{-}
$$

The high selectivity of activated alumina for fluoride compared 


\begin{tabular}{|c|c|c|c|c|}
\hline \multicolumn{5}{|c|}{$\begin{array}{c}\text { TABLE 1 } \\
\text { Recommended and maximum allowable fluoride } \\
\text { concentration for drinking water }\end{array}$} \\
\hline \multirow{2}{*}{$\begin{array}{l}\text { Annual ave- } \\
\text { rage of maxi- } \\
\text { mum daily air } \\
\text { temperatures } \\
\left({ }^{\circ} \mathrm{C}\right)\end{array}$} & \multicolumn{3}{|c|}{$\begin{array}{c}\text { Recommended fluoride } \\
\text { concentration }(\mathrm{mg} / \mathrm{l})\end{array}$} & \multirow{2}{*}{$\begin{array}{c}\text { Maximum } \\
\text { allowable } \\
\text { fluoride } \\
\text { concentration } \\
\text { (mg/l) }\end{array}$} \\
\hline & Lower & Optimum & Upper & \\
\hline $10-12.0$ & 0.9 & 1.2 & 1.7 & 2.4 \\
\hline $12.1-14.6$ & 0.8 & 1.1 & 1.5 & 2.2 \\
\hline $14.7-17.7$ & 0.8 & 1.0 & 1.3 & 2.0 \\
\hline $17.8-21.4$ & 0.7 & 0.9 & 1.2 & 1.8 \\
\hline $21.5-26.3$ & 0.7 & 0.8 & 1.0 & 1.6 \\
\hline $26.4-31.5$ & 0.6 & 0.7 & 0.8 & 1.4 \\
\hline
\end{tabular}

to synthetic anion exchangers makes it extremely suitable for fluoride removal from water containing ions such as sulphates, chlorides and bicarbonates, which may compete for the limited adsorption sites.

A typical adsorption-regeneration cycle for the removal of fluoride may be presented as follows (Clifford et al., 1978).

Acidification. When neutral (water washed) alumina, which is represented as alumina. $\mathrm{H}_{2} \mathrm{O}$, is treated with sulphuric acid, acidic alumina is formed following the reaction:

$$
\text { alumina. } \mathrm{H}_{2} \mathrm{O}+\mathrm{H}_{2} \mathrm{SO}_{4} \rightarrow \text { alumina. } \mathrm{H}_{2} \mathrm{SO}_{4}+\mathrm{H}_{2} \mathrm{O}
$$

Ion exchange (loading). Once this acidic form is brought into contact with fluoride ions, they displace the sulphate anions.

$$
\text { alumina. } \mathrm{H}_{2} \mathrm{SO}_{4}+2 \mathrm{NaF} \rightarrow \text { alumina. } \mathrm{H}_{2} \mathrm{~F}_{2}+\mathrm{Na}_{2} \mathrm{SO}_{4}
$$

Backwashing. This is carried out after loading to remove suspended solids, to redistribute the alumina particles and break up any tendency towards wall effects and channelling.

Regeneration. This is usually carried out with a dilute solution of hydroxide as the most preferred anion.

$$
\text { alumina. } \mathrm{H}_{2} \mathrm{~F}_{2}+3 \mathrm{NaOH} \rightarrow \text { alumina. } \mathrm{NaOH}+2 \mathrm{NaF}+2 \mathrm{H}_{2} \mathrm{O}
$$

Rinsing. This is necessary to remove excess regenerant from the alumina bed before neutralisation.

Neutralisation. To restore the fluoride removal capacity, the basic alumina is contacted with dilute sulphuric acid.

$$
2 \text { alumina. } \mathrm{NaOH}+3 \mathrm{H}_{2} \mathrm{SO}_{4} \rightarrow \underset{+2 \mathrm{H} O}{2 \text { alumina. } \mathrm{H}_{2} \mathrm{SO}_{4}+\mathrm{Na}_{2} \mathrm{SO}_{4}}
$$

The acidic alumina (alumina. $\mathrm{H}_{2} \mathrm{SO}_{4}$ ) is now ready for another adsorption cycle.

\section{Design criteria}

Design criteria for the full-scale plant are shown in Table 2 (Schoeman et al., 1985).

\section{Experimental}

A simplified flow diagram of the defluoridation plant is shown in Fig. 1. Borehole water is pumped through the defluoridation plant and the treated water is stored in a reservoir for distribution to the community. Spent regenerant

FR: Flow rate and backwash water is stored in a lined evaporation pond.

A number of runs were conducted and breakthrough curves established. The experimental conditions for the runs are summarised in Table 3. The breakpoint for fluoride was taken as 2.0 $\mathrm{mg} / \ell$ and the number of bed volumes (BVs, $1 \mathrm{BV}=$ volume of alumina in vessel) produced at breakthrough were determined from these curves. All fluoride analyses were carried out with a fluoride-specific electrode and the other ions were analysed with ICP-OES.

\section{Results and discussion}

\section{Plant performance}

Six loading-regeneration runs were conducted during the commissioning phase of the plant. Plant performance data for the six runs are summarised in Table 4.

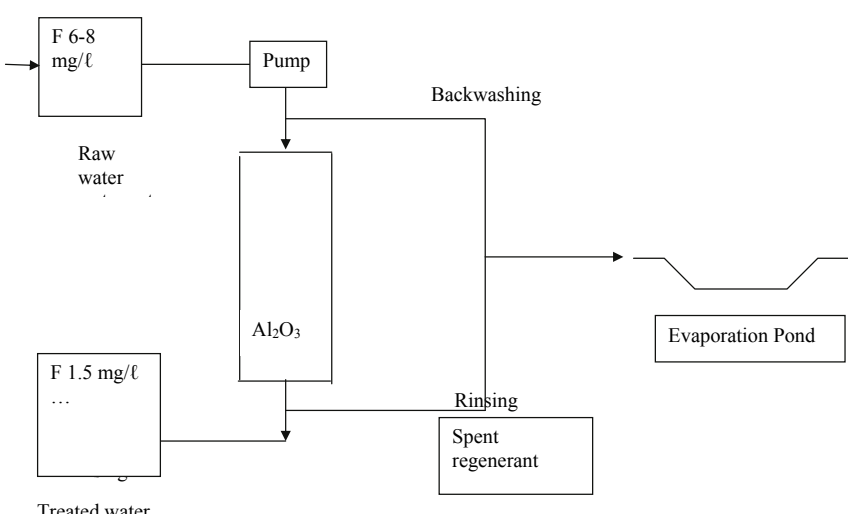

Figure 1

Simplified flow diagram of defluoridation plant

\begin{tabular}{|l|l|}
\hline \multicolumn{2}{|c|}{ TABLE 2 } \\
Design criteria for fluoride removal \\
\hline Exchange capacity $(1.5 \mathrm{mg} / \ell \mathrm{F})$ & $3.23 \mathrm{~g} \mathrm{~F} / \ell$ \\
\hline Alumina particle size & $0.5-1.0 \mathrm{~mm}$ \\
\hline Feed-water retention & $5 \mathrm{~min}$ \\
\hline Alumina bed depth & $1.0-1.5 \mathrm{~m}$ \\
\hline Regenerant flow rate & $101.7 \ell / \mathrm{m}^{2} \cdot \mathrm{min}^{1}$ \\
\hline Regenerant usage $(1.0 \% \mathrm{NaOH})$ & $5 \mathrm{bed} \mathrm{volumes}$ \\
\hline $\begin{array}{l}\mathrm{H}_{2} \mathrm{SO}_{4} \text { required for neutralisation of } \\
\text { alumina }\end{array}$ & $\begin{array}{l}1.53 \mathrm{~g} 98 \% \\
\mathrm{H}_{2} \mathrm{SO}_{4} / \ell\end{array}$ \\
\hline $\begin{array}{l}\text { Feed and neutralising acid solution flow } \\
\text { rates }\end{array}$ & $200 \ell / \mathrm{m}^{2} \cdot \mathrm{min}^{1}$ \\
\hline Backwash flow rate $(50 \%$ expansion) & $982 \ell / \mathrm{m}^{2} \cdot \mathrm{min}^{1}$ \\
\hline Rinsing flow rate & $982 \ell / \mathrm{m}^{2} \cdot \mathrm{min}^{1}$ \\
\hline $\begin{array}{l}\text { Concentration } \mathrm{H}_{2} \mathrm{SO} \\
\text { adjustment of feed water }\end{array}$ & $108 \mathrm{mg} 98 \%$ \\
\hline Total time required for regeneration $\mathrm{pH}$ & $\mathrm{H}_{2} \mathrm{SO}_{4} / \ell$ \\
\hline
\end{tabular}

\begin{tabular}{|c|c|c|c|c|c|c|c|c|}
\hline \multicolumn{10}{|c|}{ TABLE 3 } \\
\hline \multicolumn{10}{|c|}{ Summary of experimental conditions during plant runs } \\
\hline \multicolumn{2}{|c|}{ Back wash } & \multicolumn{2}{c|}{ Regenerant } & \multicolumn{2}{c|}{ Rinse } & \multicolumn{3}{c|}{ Neutralisation } \\
\hline $\begin{array}{c}\mathrm{FR} \\
\left(\mathrm{m}^{3} / \mathrm{h}\right)\end{array}$ & $\begin{array}{c}\text { Time } \\
(\mathrm{min})\end{array}$ & $\begin{array}{c}\text { Conc. } \\
(\%)\end{array}$ & $\begin{array}{c}\mathrm{FR} \\
\left(\mathrm{m}^{3} / \mathrm{h}\right)\end{array}$ & $\begin{array}{c}\mathrm{FR} \\
\left(\mathrm{m}^{3} / \mathrm{h}\right)\end{array}$ & Time & $\begin{array}{c}\mathrm{FR} \\
\left(\mathrm{m}^{3} / \mathrm{h}\right)\end{array}$ & $\begin{array}{c}\text { Time } \\
(\mathrm{min})\end{array}$ & $\begin{array}{c}\text { Acid } \\
(\%)\end{array}$ \\
\hline 82 & 10 & 1 & 8.5 & 16.9 & 59 & 16.6 & 90 & 0.25 \\
\hline
\end{tabular}

Note: The loading flow rate was $15 \mathrm{~m}^{3} / \mathrm{h}$ 


\begin{tabular}{|c|c|c|c|c|c|}
\hline \multicolumn{6}{|c|}{$\begin{array}{c}\text { TABLE } 4 \\
\text { Plant performance data at approximately } 2 \mathrm{mg} / \mathrm{l} \text { fluoride breakthrough }\end{array}$} \\
\hline Run No. & $F$ feed $(\mathrm{mg} / \mathrm{l})$ & F product $\mathrm{mg} / \mathrm{l}$ ) & Time (h) & Throughput $\left(\mathrm{m}^{3}\right)$ & BVs \\
\hline 1 & $5.9-7.4$ & 1.94 & 67.5 & 995 & 599.4 \\
\hline 2 & $6.8-10.8$ & 2.1 & 72.0 & 1057 & 636.75 \\
\hline 3 & $8.1-9.1$ & 2.0 & 67.5 & 940 & 566.27 \\
\hline 4 & $7.4-10.3$ & 2.1 & 79.5 & 1192 & 718.97 \\
\hline 5 & $5.3-6.4$ & 1.9 & 75.0 & 1208 & 727.71 \\
\hline 6 & 6.1 & 2.0 & 78.0 & 1296 & 780.72 \\
\hline
\end{tabular}

Fluoride Removal (Run5)

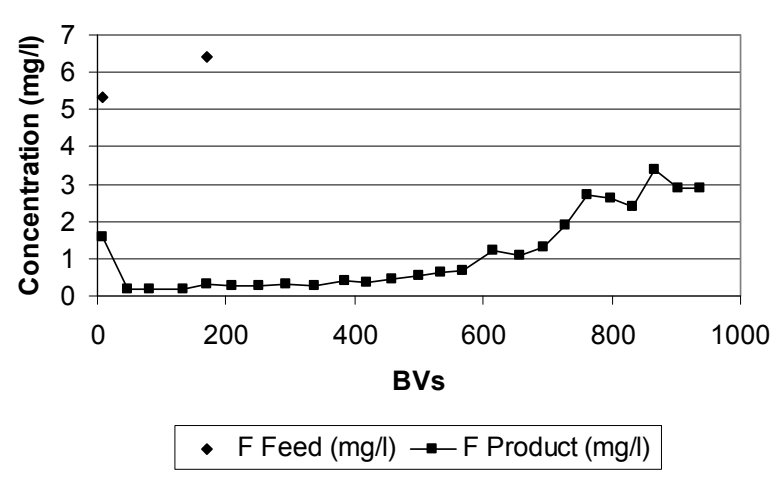

Figure 2

Fluoride concentration in the raw and treated water as a function of the number of bed volumes produced

The fluoride concentration in the feed water (5.3 to 10.8 $\mathrm{mg} / \ell$ ) could be easily reduced to $\sim 2 \mathrm{mg} / \ell$ in the treated water. The average concentration of fluoride in the treated water was approximately $1 \mathrm{mg} / \ell$. Therefore, an excellent quality water could be produced with the activated alumina defluoridation process.

The loading time to reach a breakthrough of approximately 2 $\mathrm{mg} / \ell$ in the treated water varied from 67.5 to $79.5 \mathrm{~h}$ for the 6 runs (Table 4). The throughput varied between 940 and $1296 \mathrm{~m}^{3}$ and the bed volumes produced between 566 and 781. The differences in throughput and bed volumes of defluoridated water produced could be ascribed to intermittent runs and slight changes in regeneration conditions. It was found that a run achieving a 2 $\mathrm{mg} / \ell$ fluoride breakthrough could be significantly increased by an intermittent run which gives the fluoride more time to adsorb onto the alumina.

\section{Breakthrough curves}

A typical breakthrough curves for Run 5 is shown in Fig. 2.

The fluoride concentration in the feed water could be reduced from 5 to $6 \mathrm{mg} / \ell$ to less than $1.5 \mathrm{mg} / \ell$ in the treated water. The running time to approximately $1.5 \mathrm{mg} / \ell$ fluoride breakthrough was $75 \mathrm{~h}\left(1208 \mathrm{~m}^{3}\right.$ throughput and $\left.728 \mathrm{BVs}\right)$

\section{Composition of spent regenerant}

The fluoride and silicon concentration and $\mathrm{pH}$ of the spent regenerant (regeneration after Run 4) is shown in Table 5.

The fluoride concentration in the spent regenerant showed a peak after 70 min regeneration time (Table 5). The fluoride concentration then dropped and was $370 \mathrm{mg} / \ell$ when the caustic soda regeneration was completed after $100 \mathrm{~min}$. The regeneration time was long as a result of the low viscosity of the caustic

\begin{tabular}{|c|c|c|c|}
\hline \multicolumn{4}{|c|}{ TABLE 5 } \\
\multicolumn{3}{|c|}{$\begin{array}{c}\text { Fluoride and silicon concentration and pH of } \\
\text { spent regenerant as a function of time }\end{array}$} \\
\hline Time (min) & $\begin{array}{c}\text { F concen- } \\
\text { tration } \\
\text { (mg/l) }\end{array}$ & $\begin{array}{c}\text { Si } \\
\text { concentration } \\
\text { (mg/l) }\end{array}$ & pH \\
\hline 0 & 3.7 & 13 & 6.2 \\
10 & 3.9 & 14 & 6.2 \\
20 & 4.6 & 13 & 6.3 \\
30 & 8.3 & 12 & 6.5 \\
40 & 17.4 & 7.1 & 6.9 \\
50 & 376 & 2.1 & 8.8 \\
60 & 881 & 0.9 & 9.8 \\
70 & 3670 & 5.5 & 10.5 \\
80 & 1130 & 75 & 12.4 \\
90 & 675 & 97 & 12.6 \\
100 & 370 & 116 & 12.7 \\
20 (Rinse) & 23.3 & 20 & 11.9 \\
40 & 15.4 & 8.9 & 11.1 \\
60 & 11.4 & 6.3 & 10.4 \\
20 (Neutral.) & 6.9 & 3.7 & 10.6 \\
40 & 3.1 & 5.3 & 9.7 \\
60 & 1.7 & 25 & 8.4 \\
80 & 3.4 & 43 & 6.4 \\
100 & 2.5 & 260 & 2.6 \\
\hline
\end{tabular}

lye during winter. Very little fluoride was removed during the subsequent rinsing and neutralisation steps.

The silicon started to desorb from the alumina at high $\mathrm{pH}$ when most of the fluoride had been removed from the alumina. Silicon was also desorbed from the alumina during the neutralisation step when the $\mathrm{pH}$ became lower.

\section{$\mathrm{pH}$ of the feed, acidified feed and caustic soda adjusted product water}

The $\mathrm{pH}$ of the feed and treated water (product) is shown in Table 6 (next page).

The $\mathrm{pH}$ of the feed was lowered from 7.6 to 7.8 to 6.1 to 6.6 in the acidified feed. The $\mathrm{pH}$ of the product water varied between 6.3 and 6.5. The $\mathrm{pH}$ is on the low side and should be raised to approximately 7 . It is also interesting to note that the initial $\mathrm{pH}$ of the product water was low $(\mathrm{pH} 3.8)$. This is due to acid leaching from the alumina bed after neutralisation of the alumina with acid. Care should be taken not to put too much acid through the bed during neutralisation.

\section{Electrical conductivity of the feed and product water}

After $19 \mathrm{~h}$ and $282 \mathrm{~m}^{3}$ throughput the electrical conductivity was $1292 \mu \mathrm{S} / \mathrm{cm}$ for the feed, $1318 \mu \mathrm{S} / \mathrm{cm}$ for the acid feed and $1358 \mu \mathrm{S} / \mathrm{cm}$ for the (caustic) product. The electrical conductiv- 


\begin{tabular}{|c|c|c|c|c|}
\hline \multicolumn{5}{|c|}{$\begin{array}{c}\text { TABLE } 6 \\
\text { pH of feed, acidified feed and caustic soda adjusted product water }\end{array}$} \\
\hline Time (hours) & $\begin{array}{c}\text { Throughput } \\
\left(\mathbf{m}^{3}\right)\end{array}$ & $\begin{array}{l}\text { Feed } \\
(\mathrm{pH})\end{array}$ & $\begin{array}{l}\text { Feed (acid) } \\
(\mathrm{pH})\end{array}$ & $\begin{array}{c}\text { Product } \\
\text { (caustic) }(\mathrm{pH})\end{array}$ \\
\hline 1 & 14 & 7.7 & 6.1 & 3.8 \\
\hline 19 & 282 & $7.6(278)$ & $6.6(96)$ & $6.3(0)$ \\
\hline 43 & 697 & 7.8 & 6.2 & 6.4 \\
\hline 63 & 1023 & 7.7 & 6.5 & 6.5 \\
\hline
\end{tabular}

\begin{tabular}{|c|c|c|c|}
\hline \multicolumn{4}{|c|}{$\begin{array}{c}\text { TABLE } 7 \\
\begin{array}{c}\text { Chemical composition of the feed and product water } \\
\text { (after } 15 \mathrm{~h} \text { and } 222 \mathrm{~m}^{3} \text { throughput) }\end{array}\end{array}$} \\
\hline Constituent & Feed $(\mathrm{mg} / \mathrm{l})$ & $\begin{array}{l}\text { Feed (acid) } \\
(\mathrm{mg} / \mathrm{l})\end{array}$ & $\begin{array}{c}\text { Product (caustic) } \\
(\mathrm{mg} / \mathrm{l})\end{array}$ \\
\hline $\mathrm{Al}$ & $<0.0$ & $<0.10$ & $<0.10$ \\
\hline $\mathrm{Ca}$ & 77 & & 76 \\
\hline $\mathrm{Cl}$ & 164 & & 167 \\
\hline $\mathrm{F}$ & 6.4 & 5.9 & $<0.20$ \\
\hline $\mathrm{Fe}$ & $<0.03$ & $<0.03$ & $<0.03$ \\
\hline $\mathrm{Mg}$ & 28 & & 28 \\
\hline $\mathrm{Na}$ & 198 & & 205 \\
\hline $\mathrm{SO}_{4}$ & 139 & 219 & 310 \\
\hline Alkalinity $\left(\mathrm{CaCO}_{3}\right)$ & 263 & 177 & 129 \\
\hline
\end{tabular}

ity of feed and product water increased somewhat after the addition of chemicals (acid and caustic soda) for $\mathrm{pH}$ control.

\section{Chemical composition of the feed and product water}

The chemical composition of the feed and product water is shown in Table 7.

Alkalinity is reduced through the addition of acid and by adsorption on the activated alumina. However, a significant amount of alkalinity is still entering the alumina bed in this case and this alkalinity reduces the capacity of the alumina for fluoride removal because if competes with fluoride for adsorption sites. It is further interesting to note that aluminium is released into the product water $(0.1 \mathrm{mg} / \ell)$ (Table 7$)$. However, the aluminium concentration in the treated water is less than $0.3 \mathrm{mg} / \ell$ which shows that the water is of acceptable quality according to the South African specifications for drinking water ((Schutte, 2006). Care should be taken, however, that the $\mathrm{pH}$ of the treated water should not drop too low $(<6)$ during neutralisation because the aluminium ion could dissolve in the water at a too low $\mathrm{pH}$. The sodium concentration of the product water increases somewhat as a result of caustic soda addition while the sulphate concentration increases as a result of acid addition and displacement of sulphate ions from the alumina by fluoride adsorption.

\section{Economics}

The capital costs of a $200 \mathrm{~m}^{3} / \mathrm{d}$ defluoridation plant are estimated at R1.3 m. Operational costs are estimated as follows:

Caustic soda regeneration:

Sulphuric acid neutralisation:

Sulphuric acid for $\mathrm{pH}$ control:

Caustic soda for $\mathrm{pH}$ control:

Electrical energy cost for pumping:
$\mathrm{R} 0.35 / \mathrm{m}^{3}$

$\mathrm{R} 0.07 / \mathrm{m}^{3}$

$\mathrm{R} 0.16 / \mathrm{m}^{3}$

$\mathrm{R} 0.14 / \mathrm{m}^{3}$

$\mathrm{R} 0.06 / \mathrm{m}^{3}$

$\mathrm{R} 0.68 / \mathrm{m}^{3}$
Note: Acid cost R0.82/kg

Caustic soda cost R2.98/kg

Electrical energy cost R0.25/kWh (2003)

\section{Conclusions}

- The water defluoridation plant was commissioned successfully and the plant is performing satisfactorily. Fluoride in the feed water present in the 6 to $10 \mathrm{mg} / \ell$ range is reduced to $<1.5 \mathrm{mg} / \ell$, the recommended maximum concentration.

- No reduction in plant output was experienced over 6 loading-regeneration cycles. Therefore, it appears that fouling of the activated alumina should not be a problem. This matter, however, should be monitored over a more extended period

- Plant output varied between 940 and $1296 \mathrm{~m}^{3}$ to a fluoride breakthrough of approximately $2.0 \mathrm{mg} / \ell$. It is recommended that the plant be regenerated after at least $940 \mathrm{~m}^{3}$ of defluoridated water has been produced.

- Care should be taken that the $\mathrm{pH}$ of the treated water should not drop too low after neutralisation of the alumina bed with acid to ensure that the aluminium ion does not go into solution.

- The capital cost of a $200 \mathrm{~m}^{3} / \mathrm{d}$ activated alumina defluoridation plant is estimated at $\mathrm{R} 1.3 \mathrm{~m}$. Operational costs are estimated at $\mathrm{R} 0.68 / \mathrm{m}^{3}$.

- It was demonstrated that a $1^{\text {st }}$ world technology could be effectively operated and maintained in a rural area with proper training and constant supervision of the operators.

\section{References}

AGARWAL M, RAI K, SHRIVASTAV R and DASS S (2003) Defluoridation of water using amended clay. J. Clean. Prod. 11 439-444.

BENEBERU S, FELEKA Z and SING CB (2006) Removal of excess fluoride from water by aluminium hydroxide. Bull. Chem. Soc. Ethiopia 20 (1) 17-34.

BISHOP PL and SANCOUCY G (1978) Fluoride removal from drink- 
ing water by fluidized activated alumina adsorption. J. Am. Water Works Assoc. 70554.

COETZEE PP, COETZEE LL, PUKA R and MUBENGA S (2003) Characterisation of selected South African clays for defluoridation of natural waters. Water SA 29 (3) 331-337. http://www.wrc.org.za/ archives/watersa\%20archive/2003/july/13.pdf

CLIFFORD D, MATSON J and KENNEDY R (1978) Activated alumina: Rediscovered "adsorbent" for fluoride, humic acids and silica. Ind. Water Eng. 15 (6).

DRINKING WATER STANDARDS (1962) US Public Service, Washington, DC.

FRIK SCHUTTE (ed.) (2006) Handbook for the Operation of Water Treatment Works. WRC Report No. TT 265/06. Water Research Commission, Pretoria, South Africa. ISBN 1-77005-428-6

HOLDEN WS (ed.) (1970) Fluoridation of Water Supplies. In: Water Treatment and Examination. J and A Churchill, London.

JAMODE AVJ, APKAL VSS and AMODE VSJ (2004) Defluoridation of water using inexpensive adsorbents. J. Indian Inst. Sci. $84163-$ 171.

MEKONEN A, KUMAR P and KUMAR A (2001) Integrated biological and physiochemical treatment process for nitrate and fluoride removal. Water Res. 35 (13) 3127-3136.

MENKOUCHI SAHLI MA, ANNOUAR S, TAHAIKT M, MOUNTADAR M, SOUFIANE A and ELMIDAOUI A (2007) Fluoride removal for underground brackish water by adsorption on the natural chitosan and by electrodialysis. Desalination 212 37-45.
NATIONAL INTERIM PRIMARY DRINKING WATER REGULATIONS (1975) EPA Federal Register. 4051.

SA BUREAU OF STANDARDS, SPECIFICATION FOR WATER FOR DOMESTIC SUPPLIES (Metric Units) (1971) SABS Specification No. 241 (supersedes SABS 241 - 1951). Pretoria, South Africa.

SCHOEMAN JJ and BOTHA GR (1985) An evaluation of the activated alumina process for fluoride removal from drinking water and some factors influencing its performance. Water SA 11 (1) 25-32.

SCHOEMAN JJ and STEYN A (2000) Defluoridation, denitrification and desalination of water using ion-exchange and reverse osmosis technology. Water Research Commission, PO Box 824, Pretoria, 0001, South Africa. ISBN 1868455971.

SORDO JA, VANDERBEMDEN P, COHEN D and CONRAD HM (1998) 65000 GPD fluoride removal membrane system in Lakeland, California, USA. Desalination 117(1) 19-35.

SOUTH AFRICAN WATER QUALITY GUIDELINES (1996) Volume 1: Domestic Water Use ( $2^{\text {nd }}$ edn.). Department of Water Affairs and Forestry, Private Bag X313, Pretoria 0001.

TAHAIKT M, ACHARY I, MENKOUCHI SAKLI MA, AMOR Z, TAKY M, ALAMI A, BOUGHRIBA A, HAFSI M and ELMIDAOUI A (2006) Defluoridation of Moroccan groundwater by electrodialysis: Continuous operation. Desalination 189 215-220.

TURNER BD, BINNING P and STIPP SLS (2005) Fluoride removal by calcite: Evidence for fluorite precipitation and surface adsorption. Environ. Sci. Technol. 39 (24) 9561-9568. 
Available on website http://www.wrc.org.za ISSN 0378-4738 = Water SA Vol. 35 No. 1 January 2009

ISSN 1816-7950 = Water SA (on-line) 